\title{
Tingkat Pencemaran Berdasarkan Saprobitas Plankton di Perairan Pelabuhan Benoa, Kota Denpasar, Provinsi Bali
}

\author{
Ni Putu Eva Damayanti a*, I Wayan Gede Astawa Karanga, Elok Faiqoha \\ a Program Studi Ilmu Kelautan, Fakultas Kelautan dan Perikanan, Universitas Udayana, Badung, Bali, Indonesia \\ * Penulis koresponden. Tel.: +62-857-370-760-80 \\ Alamat e-mail: n.p.evadamayanti@gmail.com
}

Diterima (received) 11 Juni 2017; disetujui (accepted) 3 September 2017; tersedia secara online (available online) 5 September 2017

\begin{abstract}
Plankton is organism that susceptible to environmental changes that used as indicator of environmental pollution by saprobic index because plankton has important role in affecting the water primary productivity. The research about plankton saprobic in Benoa Harbour is never done before. The aim of this research is to explain the structure of community and the level of plankton saprobic at Benoa Harbour. This research using random sampling method for determine the station. The result explained that there was 17 species of plankton in the waters of Benoa Harbor from two classes such as Bacillariophyceae, Dinophyceae on phytoplankton and from five classes such as Magnoliopsida, Malacostraca, Maxillopoda, Globothalamea and Hexanauplia on zooplankton. The total abundance of plankton ranges from 1.117.172 Individual / Liter- 1.626.163 Individual / Liter. The zooplankton diversity index in the waters of Benoa Harbor ranges from 1.06 to 1.58 and phytoplankton ranges from 1.02 to 155 . This indicates that the value of diversity in all observation stations is categorized into low biodiversity. Zooplankton evenness index value in the waters of Benoa Harbor ranged from 0.73-0.88 and phytoplankton ranged from 0.71-0.96. This indicates that the index of evenness is relatively high. The dominant value of zooplankton in the waters of Benoa Harbor ranges from 0.24-0.43 and phytoplankton ranged from $0.22-0.41$. This indicates that the dominance is relatively low. Saprobik Index (SI) value ranges from 1.0-1.6 and Tropic Saprobic Index (TSI) ranges from 1.76-1.96. This indicates that the waters of Benoa Harbour is categorized mild contaminated conditions until not contaminated.
\end{abstract}

Keywords: community structure; plankton; saprobic; Benoa Harbor

\begin{abstract}
Abstrak
Plankton merupakan organisme yang rentan terhadap perubahan lingkungan sehingga dapat dijadikan indikator pencemaran lingkungan melalui indeks saprobitas karena plankton berperanan penting dalam mempengaruhi produktivitas primer suatu perairan. Penelitian terkait saprobitas plankton di perairan Pelabuhan Benoa belum pernah dilakukan sebelumnya. Tujuan dari penelitian ini yaitu untuk mengetahui struktur komunitas dan tingkat saprobitas plankton di Pelabuhan Benoa.Penelitian ini menggunakan metode random sampling untuk penentuan stasiunnya. Dari hasil penelitian ditemukan 17 jenis plankton di perairan Pelabuhan Benoa yaitu dari 2 kelas Bacillariophyceae, Dinophyceae pada fitoplankton dan 5 kelas Magnoliopsida, Malacostraca, Maxillopoda, Globothalamea dan Hexanauplia pada zooplankton. Kelimpahan total plankton berkisar 1.117.172 Individu/Liter- 1.626.163 Individu/Liter. Indeks keanekaragaman zooplankton di perairan Pelabuhan Benoa berkisar 1.06-1.58 dan fitoplankton berkisar 1.02155. Hal ini menunjukan bahwa nilai keanekaragaman pada seluruh stasiun pengamatan termasuk dalam kategori keanekaragaman rendah. Nilai indeks keseragaman zooplankton di perairan Pelabuhan Benoa berkisar 0.73-0.88 dan fitoplankton berkisar 0.71-0.96. Hal ini menunjukan bahwa indeks keseragaman relatif tinggi. Nilai dominansi zooplankton di perairan Pelabuhan Benoa berkisar 0.24-0.43 dan fitoplankton berkisar 0.22-0.41. Hal ini menunjukan bahwa dominansi yang relatif rendah. Nilai Saprobik Indeks (SI) berkisar 1.0-1.6 dan Tingkat Saprobik Indeks (TSI) berkisar 1.76-1.96. Hal ini menunjukkan bahwa perairan Pelabuhan Benoa dikategorikan perairan dalam kondisi tercemar ringan sampai belum tercemar.
\end{abstract}

Kata Kunci: struktur komunitas; plankton;saprobitas; Pelabuhan Benoa 


\section{Pendahuluan}

Pencemaran perairan merupakan menurunnya kualitas air yang disebabkann oleh masuknya organisme dan komponen lainnya sehingga perairan tersebut tidak berfungsi lagi sesuai dengan peruntukannya. Salah satu organisme yang dapat digunakan sebagai indikator pencemaran yaitu plankton (Anggraini, 2016; Gharib et al., 2011). Penggunaan plankton untuk mencari indikator pencemarain menggunakan tingkat saprobitas suatu perairan. Saprobitas perairan indikatornya yaitu suatu spesies dari organisme untuk melihat kondisi perairan yang disebabkan oleh penambahan bahan organik pada suatu perairan (Utomo et al., 2013). Menurut Makmur et al. (2013), air limbah industri dan limbah domestik yang mengandung zat-zat pencemar yang tinggi dapat menyebabkan degradasi lingkungan yang dibuang ke perairan sungai. Selanjutnya menurut Damaianto et al., (2014), bahwa air limbah yang tidak diolah dengan baik berpotensi mencemari lingkungan perairan pesisir dan laut.

Kelimpahan jumlah jenis plankton merupakan biomonitoring untuk kualitas perairan yang erat hubungannya dengan perubahan faktor lingkungan (Junqueira et al., 2010). Perubahan faktor lingkungan dapat disebabkan oleh banyaknya aktivitas manusia di suatu daerah yang menghasilkan sampah dan limbah dalam jumlah besar (Amengual-Morro et al., 2012). Salah satu daerah diantaranya adalah kegiatan di daerah pelabuhan, yaitu pada daerah pelabuhan Benoa. Pelabuhan Benoa adalah pelabuhan buatan yang dibangun sekitar tahun 1920 dengan posisi geografi spada $08^{\prime}-45^{\prime}-00^{\prime \prime}$ LS dan $115^{\prime}-13^{\prime}-00^{\prime \prime}$ BT, dengan jarak kurang lebih $10 \mathrm{~km}$ dari ibukota Denpasar. Keberadaan pelabuhan sebagai salah satu subsistem transportasi mempunyai peranan strategis karena merupakan mata rantai yang mempertemukan dua atau lebih jenis transportasi. Di sekitar Pelabuhan Benoa terdapat berbagai aktivitas diantaranya kegiatan jasa, tempat wisata, bersandar kapal-kapal penumpang, dan berbagai aktivitas nelayan yang dapat menghasilkan sampah dan limbah organik maupun anorganik dalam jumlah yang besar. Hal tersebut mengindikasikan bahwa banyaknya aktivitas di sekitar Pelabuhan Benoa dapat menjadi salah satu sumber pencemar bagi perairan.

Penelitian tentang pencemaran yang menggunakan parameter kimia di sekitar perairan
Pelabuhan Benoa, yang telah dilakukan sebelumnya seperti pencemaran logam berat $\mathrm{Fe}$ dan Mn (Sahara et al., 2015) didapatkan konsentrasi $\mathrm{Fe}$ dan $\mathrm{Mn}$ yang ditemukan pada penelitian ini berada di atas standar baku mutu Environmental Protection Agency. Penelitian pencemaran menggunakan pendekatan biologi berdasarkan saprobitas plankton belum pernah dilakukan di perairan Pelabuhan Benoa, namun sudah pernah dilakukan di Pesisir Kenjeran Surabaya, Muara Sungai Morodemak, dan perairan estuaria Kuala Gigieng Kabupaten Aceh Besar, Provinsi Aceh (Hariaty et al., 2010; Suryanti,2008; Sarinda et al., 2013). Koefisien saprobik digunakan untuk mengetahui tingkat ketergantungan atau hubungan suatu organisme dengan senyawa yang menjadi sumber nutrisinya sehingga dapat diketahui hubungan kelimpahan, keanekaragaman, dan keseragaman plankton. Penelitian tingkat pencemaran berdasarkan saprobitas plankton di perairan Pelabuhan Benoa penting dilakukan untuk dijadikan data dasar dalam pengambilan keputusan untuk pengelolaan kawasan Teluk Benoa. Tujuan dari penelitian ini yaitu untuk mengetahui struktur komunitas dan tingkat saprobitas plankton di Pelabuhan Benoa.

\section{Metode Penelitian}

\subsection{Waktu dan Lokasi Penelitian}

Penelitian ini dilaksanakan di perairan Pelabuhan Benoa, Denpasar, Bali (Gambar 1). Pengambilan sampel dilakukan pada saat pasang purnama (spring tide) dan saat kondisi pasang menuju surut, pada tanggal 12 Desember 2017, di sekitaran Pelabuahan Benoa yang meliputi dari 8 (delapan) stasiun penelitian. Keberadaan stasiun 1 berada dekat mangrove dan kapal-kapal berlabuh. Stasiun 2 dan stasiun 3 keberadaannya dekat dengan kapal-kapal berlabuh. Stasiun 4, stasiun 5 dan stasiun 6 keberadaannya dekat dengan kapal pengangkut minyak. Stasiun 7 keberadaannya dekat dengan kapal perikanan, dan stasiun 8 keberadaannya dekat pada pertemuan antara Pulau Serangan dengan Tanjung Benoa.

\subsection{Alat dan Bahan}

Pada penelitian mengenai tingkat pencemaran berdasarkan saprobitas plankton ini digunakan beberapa alat (Tabel 1). 


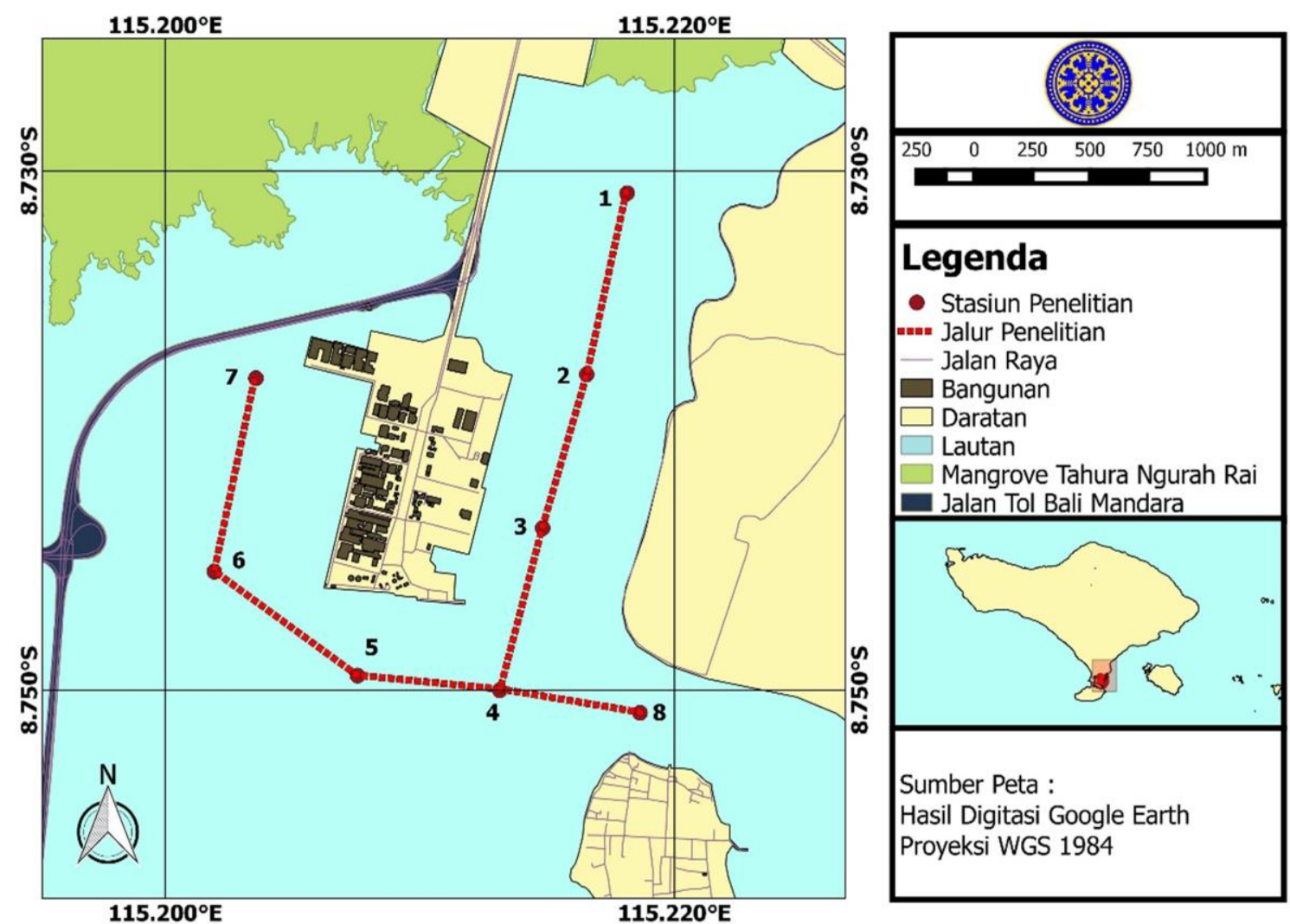

Gambar 1. Peta Lokasi Penelitian

Tabel 1

Daftar Alat Penelitian

\begin{tabular}{cll}
\hline No & \multicolumn{1}{c}{ Nama Alat } & \multicolumn{1}{c}{ Kegunaan } \\
\hline 1 & $\begin{array}{l}\text { GPS (Global } \\
\text { Positioning } \\
\text { System) }\end{array}$ & $\begin{array}{l}\text { Menentukan titik koordinat } \\
\text { pengambilan sampel }\end{array}$ \\
2 & $\begin{array}{l}\text { Sedgwick Rafter } \\
\text { Tempat untuk mengamati } \\
\text { sampel plankton yang telah } \\
\text { tersaring }\end{array}$ \\
& $\begin{array}{l}\text { Buku } \\
\text { identifikasi } \\
\text { plankton }\end{array}$ & $\begin{array}{l}\text { Membantu dalam proses } \\
\text { identifikasi plankton }\end{array}$ \\
4 & Kamera & Alat untuk dokumentasi \\
5 & Optilab & Untuk membantu \\
& & mengamati sampel plankton \\
& & yang tersambung pada \\
& & laptop \\
\hline
\end{tabular}

Adapun bahan yang digunakan selama penelitian diantaranya, lugol yang berfungsi memberikan warna pada sampel plankton; formalin yang berfungsi untuk mengawetkan sampel plankton; aquades yang berfungsi untuk membersihkan alat-alat penelitian; dan sampel plankton berfungsi sebagai bahan penelitian yang kemudian diidentifikasi.

\subsection{Metode Penelitian}

\subsubsection{Penentuan Staisun Penelitian}

Penelitian ini menggunakan metode random sampling atau sampel acak untuk menentukan stasiun pengamatan. Metode random sampling adalah suatu cara pengambilan sampel secara acak dimana setiap anggota dari populasi memiliki kesempatan yang sama untuk dipilih menjadi sampel dan tidak ada pertimbangan tertentu dari peneliti. Jumlah stasiun pengamatan pada penelitian ini sebanyak delapan stasiun agar dapat mewakili seluruh perairan di Pelabuhan Benoa.

\subsubsection{Pengambilan Sampel Plankton}

Sampel plankton yang diambil menggunakan plankton net yang dilengkapi dengan botol penampung berukuran 1 liter untuk penampung sampel yang tersaring. Sampel plankton diambil secara horizontal menggunakan plankton net dengan ditarik menggunakan perahu berjarak 800 m dengan kecepatan 5 km/jam.. Kemudian sampel plankton yang telah tersaring dipindahkan ke dalam botol sampel berukuran $100 \mathrm{ml}$. Sampel tersebut diawetkan dengan menggunakan larutan formalin $4 \%$ dan lugol sebanyak 2 tetes. Masing- 
masing botol sampel ditempelkan kertas label berdasarkan stasiun pengambilan sampel.

\subsubsection{Identifikasi Sampel Plankton}

Botol sampel yang berisi sampel plankton dihomogenkan kemudian sampel yang diambil menggunakan pipet tetes dan diteteskan kedalam kaca preparat. Kaca preparat diletakan di bawah mikroskop binokuler. Sampel diamati dengan menggunakan Sedgewick-Rafter Counting Cell sebanyak tiga kali pengulangan dengan perbesaran $10 \times 10$. Kemudian dilakukan pencacahan serta identifikasi menggunakan buku identifikasi Marine Plankton dan Coastal Plankton dari G.E Newell dan R.C Newell, untuk menghitung kelimpahan, keanekaragaman, keseragaman, indeks dominansi, Saprobik Indeks (SI), dan Tingkat Saprobik Indeks (TSI) plankton. Identifikasi jenis plankton dilakukan di Laboratorium Ilmu Kelautan, Fakultas Kelautan dan Perikanan, Universitas Udayana.

\subsubsection{Pengambilan Sampel Parameter Kualitas Air}

Pengambilan sampel parameter fisika dan kimia perairan sangat diperlukan untuk mengetahui kondisi lingkungan di perairan Pelabuhan Benoa, serta mengetahui untuk kehidupan plankton. Pengukuran suhu, salinitas, derajat keasaman, dan kekeruhan dilakukan secara in situ. Sedangkan sampel nutrient (nitrat dan fosfat) dianalisis di Laboratorium Kesehatan Provinsi Bali.

\subsection{Analisa Data}

Data plankton dihitung dan analisis dengan beberapa parameter sebagai berikut.

\subsubsection{Analisis Kelimpahan}

Pengukuran kelimpahan plankton dihitung dengan menggunakan metode perhitungan Sedgewick-Rafter di bawah mikroskop binokuler dengan satuan individu/liter (ind/l) pada persamaan 1.

$N=n \frac{V t}{V o} \times \frac{A c g}{A a} \times \frac{1}{V d} \times 1000$

Vd horizontal : R $x$ a $\times \mathrm{p}$

dimana, $\mathrm{N}$ adalah Kelimpahan (ind/l), $\mathrm{n}$ adalah Jumlah plankton yang diidentifikasi, Vt: adalah Volume air tersaring dalam botol $(100 \mathrm{ml})$, V0 adalah Volume air pada Sedgewick-Rafter Counting Cell (1ml), Acg adalah Luas Sedgewick-Rafter yang diamati $\left(1000 \mathrm{~mm}^{2}\right)$, Aa adalah Luas petak Sedgewick-Rafter yang diamati $\left(1000 \mathrm{~mm}^{2}\right)$, Vd adalah Volume air tersaring $\left(\mathrm{m}^{3}\right)$, $\mathrm{R}$ adalah Jumlah rotasi baling-baling flowmeter, a adalah Luas mulut jarring $\left(\mathrm{m}^{2}\right)$, $\mathrm{p}$ adalah Koefisien kalibrasi flowmeter (panjang kolom air yang ditempuh untuk satu rotasi baling-baling flowmeter.

\subsubsection{Indeks Struktur Komunitas}

\section{a. Indeks Keanekaragaman}

Untuk Penghitungan indeks keanekaragaman fitoplankton dan zooplankton digunakan Indeks Shannon-Wiener dengan persamaan 2.

$$
H^{\prime}=-\sum_{i=1} P i \ln P i, P i=\frac{n i}{n}
$$

dimana, $\mathrm{H}^{\prime}$ adalah indeks keanekaragaman, ni adalah jumlah individu jenis ke- $1, \mathrm{n}$ adalah jumlah individu total. Penggolongan kondisi komunitas biota berdasarkan $\mathrm{H}^{\prime}$ (Basmi, 1999) adalah: $\mathrm{H}^{\prime}<$ 2,30 merupakan keanekaragaman kecil dan kestabilan komunitas rendah., 2,30 $<\mathrm{H}^{\prime}<6,91$ merupakan keanekaragaman sedang dan kestabilan komunitas sedang, $\mathrm{H}^{\prime}>6,91$ merupakan keanekaragaman tinggi dan kestabilan komunitas tinggi.

\section{b. Indeks Keseragaman}

Analisis indeks keseragaman fitoplankton dan zooplankton menggunakan persamaan 3 .

$$
E=\frac{H^{\prime}}{\text { Hmaks }} ; \text { Hmaks }=\ln S
$$

dimana, $\mathrm{E}$ adalah indeks keseragaman, $\mathrm{H}^{\prime}$ adalah indeks keanekaragaman, $\mathrm{S}$ adalah jumlah jenis

\section{c. Indeks Dominansi}

Perhitungan indeks dominansi untuk fitoplankton dan zooplankton menggunakan indeks dominansi Simpson pada persamaan 4 .

$$
C=\sum\left(\frac{n i}{n}\right)^{2}
$$

dimana, $\mathrm{C}$ adalah indeks dominansi Simpson, ni adalah jumlah individu ke-i, $\mathrm{n}$ adalah jumlah total individu.

2.4.3 Saprobik Indeks (SI) dan Tingkat Saprobik Indeks (TSI)

Saprobik Indeks merupakan indeks yang digunakan untuk menghitung jumlah yang 
tergolong spesies status pencemaran organik pada perairan Sedangkan Total Saprobik Indeks merupakan indeks yang digunakan untuk menghitung jumlah individu penyusun kelompok status pencemaran organik pada perairan. Indeks ini menggunakan keberadaan organisme yang hadir di perairan untuk menentukan status perairan (Ramadhan et al., 2016). Untuk menghitung Saprobik Indeks (SI) digunakan persamaan 5 .

$S I=\frac{1 C+3 D+1 B-3 A}{1 A+1 B+1 C+1 D}$

dimana, SI adalah Saprobik Indeks, A adalah jumlah spesies organisme polysaprobik, B adalah jumlah spesies organisme $\alpha$-mesosaprobik, C adalah jumlah spesies organisme $\beta$-mesosaprobik, $\mathrm{D}$ adalah jumlah spesies organisme oligosaprobik.

Untuk menghitung Tingkat Saprobik Indeks (TSI) digunakan persamaan 6 .

$$
\begin{aligned}
& T S I=\frac{1(n) C+3(n D)+n B-3(n A)}{1(n A)+3(n B)+1(n C)+1(n) D} \\
& x \frac{n A+n B+n C+n D+n E}{n A+n B+n C+n D}
\end{aligned}
$$

dimana, $\mathrm{n}$ jumlah Jumlah individu organisme pada setiap kelompok saprobitas, nA adalah Jumlah individu penyusun kelompok Polysaprobik, nB adalah Jumlah individu penyusun kelompok $\alpha$-Mesosaprobik, nC adalah Jumlah individu penyusun kelompok $\beta$ Mesosaprobik, nD adalah Jumlah individu penyusun kelompok Oligosaprobik, nE adalah Jumlah individu penyusun selain A, B, C dan D.

Nilai indeks keanekaragaman, Saprobik Indeks (SI) dan Tingkat Saprobik Indeks (TSI) dapat dihubungkan dengan tingkat saprobitas dan kondisi suatu perairan, berdasarkan organisme saprobik yang mendominasi di suatu perairan, maka tingkat pencemaran dapat dibagi menjadi empat tingkat yaitu pencemaran berat, pencemaran sedang sampai berat, pencemaran ringan sampai sedang, dan pencemaran ringan atau belum tercemar (Tabel 2).

\section{Hasil dan Pembahasan}

\subsection{Komposisi Jenis Plankton di Perairan Pelabuhan Benoa}

\subsubsection{Komposisi Jenia Fitoplankton}

Jenis fitoplankton yang ditemukan di perairan Pelabuhan Benoa terdapat 2 kelas dan 9 jenis. Fitoplankton pada kelas Bacillariophyceae yang banyak dijumpai yaitu jenis Skeletonema sp. dengan jumlah yang ditemukan jumlahnya 38 individu, sedangkan jenis yang paling sedikit ditemukan yaitu jenis Thalassiothrix $s p$. dengan jumlah 3 individu yang ditemukan. Namun, jenis pada kelas Dinophyceae yang ditemukan 1 jenis yaitu Ceratium.sp yang paling banyak ditemukan di perairan Pelabuhan Benoa yaitu 59 individu. Secara keseluruhan kelompok fitoplantkon dengan komposisi tertinggi yaitu pada kelas Bacillariophyceae dengan total komposisi 147 individu, sedangkan kelas Dinophyceae dengan komposisi 59 individu, dengan total komposisi untuk semua jenis yaitu 206 individu.

\section{Tabel 2}

Hubungan Keanekaragaman Plankton dengan Tingkat

\begin{tabular}{|c|c|c|c|}
\hline $\begin{array}{l}\text { Nilai SI } \\
\text { dan TSI }\end{array}$ & $\mathrm{H}^{\prime}$ & $\begin{array}{c}\text { Tingkat } \\
\text { Saprobitas }\end{array}$ & Indikasi \\
\hline $\begin{array}{c}<-3 \mathrm{~s} / \mathrm{d}- \\
2\end{array}$ & $<1$ & Polisaprobik & $\begin{array}{l}\text { Pencemaran } \\
\text { berat }\end{array}$ \\
\hline$-2 \mathrm{~s} / \mathrm{d} 0,5$ & $1-1,5$ & $\alpha$ - Mesosaprobik & $\begin{array}{l}\text { Pencemaran } \\
\text { sedang } \\
\text { sampai berat }\end{array}$ \\
\hline $0,5 \mathrm{~s} / \mathrm{d} 1,5$ & $1,5-2$ & $\beta$ - Mesosaprobik & $\begin{array}{l}\text { Pencemaran } \\
\text { ringan } \\
\text { sampai } \\
\text { sedang }\end{array}$ \\
\hline $1,5 \mathrm{~s} / \mathrm{d} 2,0$ & $>2$ & Oligosaprobik & $\begin{array}{l}\text { Pencemaran } \\
\text { ringan/ } \\
\text { belum } \\
\text { tercemar }\end{array}$ \\
\hline
\end{tabular}
Pencemaran Perairan

Berdasarkan hasil presentase komposisi jenis fitoplankton, menunjukan jenis yang memiliki komposisi tertinggi yaitu pada kelas Bacillariophyceae dengan presentase komposisi sebesar $71.36 \%$, sedangkan kelas Dinophyceae memiliki presentase komposisi sebesar $28.64 \%$ (Gambar 2). Maka, jenis yang paling banyak ditemukan di perairan Pelabuhan Benoa adalah jenis dari kelas Bacillariophyceae.

Keberadaannya tinggi pada kelas Bacillariophyceae diduga karena jenis ini bersifat kosmopolit atau organisme yang mampu hidup di berbagai kondisi perairan dan memiliki tingkat toleransi yang tinggi terhadap perubahan lingkungan. Kelas Bacillariophyceae umumnya ditemukan di laut, dalam kondisi cuaca yang berubah-ubah. Ini sesuai pendapat yang dikemukakan oleh Nontji (2008), bahwa diatom 
(Bacillariophyceae) merupakan jenis dari golongan fitoplankton yang paling umum dijumpai di laut. Namun, tingginya jenis Ceratium sp. pada kelas Dinophyceae diduga karena merupakan harmful spesies yang dapat membahayakan perairan jika terjadi ledakan populasi/blooming, menurut Thoha dan Rachman (2013), blooming fitoplankton khususnya dinoflagellata bila kelimpahannya $>5000 \mathrm{sel} / \mathrm{L}$, tetapi hal ini tetap saja berbahaya dikarenakan mengandung racun yang dapat masuk ke rantai makanan.

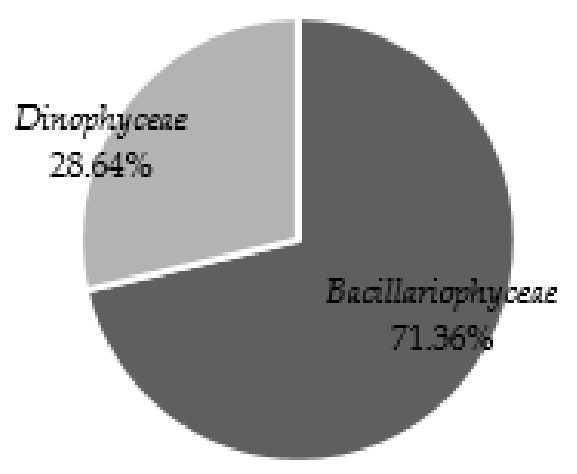

Gambar 2. Presentase Komposisi Jenis Fitoplankton

\subsubsection{Komposisi Jenis Zooplankton}

Jenis zooplankton yang ditemukan di perairan Pelabuhan Benoa terdapat 5 kelas dan 8 jenis. Zooplankton yang banyak dijumpai yaitu jenis Palaemon sp. dengan jumlah yang ditemukan jumlahnya 93 jenis, sedangkan jenis yang paling sedikit ditemukan yaitu jenis Euterpina sp. dengan jumlah 6 jenis yang ditemukan. Secara keseluruhan kelompok zooplankton dengan komposisi tertinggi yaitu pada kelas Malacostraca dengan total komposisi 307 individu, sedangkan kelas Maxillopoda dengan komposisi 149 individu, kelas Magnoliopsida dengan komposisi 11 individu, kelas Hexanauplia dengan komposisi 3 individu dan kelas Globothalamea dengan komposisi 1 individu, dengan total komposisi untuk semua jenis yaitu 471 individu.

Berdasarkan hasil presentase komposisi jenis zooplankton, menunjukan jenis yang memiliki komposisi tertinggi yaitu pada kelas Malacostraca dengan presentase komposisi sebesar $65.18 \%$, sedangkan kelas Maxillopoda memiliki presentase komposisi sebesar 31.63\%, kelas Magnolopsida memiliki presentase komposisi $2.34 \%$, kelas Hexanauplia memiliki presentase komposisi $0.64 \%$, kelas Globothalamea memiliki presentase komposisi $0.21 \%$. Maka, jenis yang paling banyak ditemukan di perairan Pelabuhan Benoa adalah jenis dari kelas Malacostraca pada filum Arthropoda (Gambar 3). Sesuai pernyataan (Rahayu,2013), bahwa zooplankton yang mendiami ekosistem perairan sebagian besar didominansi oleh filum Arthropoda yaitu sebanyak $70-90 \%$.

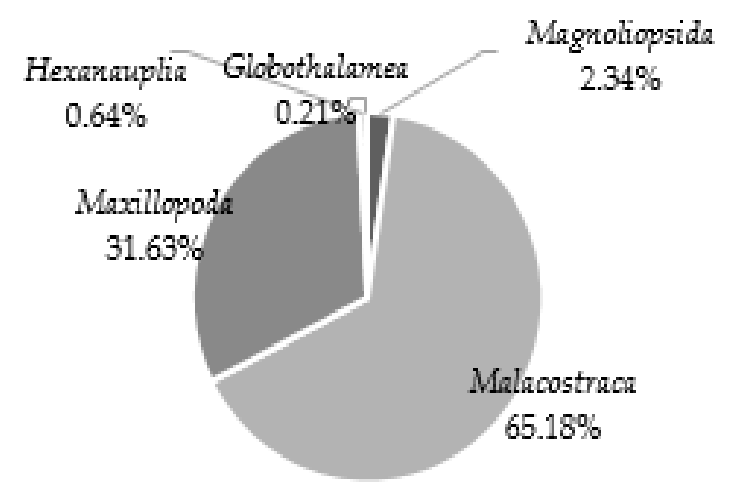

Gambar 3. Presentase Komposisi Jenis Zooplankton

Kelas Malacostraca merupakan jenis udangudangan. Komposisi jenisnya tinggi diduga karena proses pemijahan yang terjadi di sekitas perairan Pelabuhan Benoa. Menurut Nastiti et al.,(2016), udang melakukan pemijahan di perairan yang relatif dalam. Setelah menetas, larvanya yang bersifat planktonis terapung-apung dibawa arus, kemudian berenang mencari air dengan salinitas rendah disekitar pantai atau muara sungai. Di kawasan pantai, larva udang tersebut berkembang. Menjelang dewasa, udang tersebut beruaya kembali ke perairan yang lebih dalam dan memiliki tingkat salinitas yang lebih tinggi, untuk kemudian memijah. Udang dalam pertumbuhan dan perkembangannya mengalami beberapa fase, yaitu nauplius, zoea, mysis, post larva, juvenile (udang muda), dan udang dewasa.

Teritip merupakan salah satu jenis pada kelas Maxillopoda yang termasuk dalam komposisi jenis tertinggi kedua. Ditemukan banyak teritip pada kapal-kapal yang bersandar di perairan Pelabuhan Benoa. Hal tersebut diduga teritip melakukan pemijahan dengan menempel di kapal yang masih tergenang air. Menurut, Boesono (2008)faktorfaktor yang mempengaruhi pertumbuhan biota penempel pada lambung kapal adalah kontruksi kapal, bentuk lambung, kecepatan kapal, dan lamanya waktu yang digunakan untuk bersandar 
di pelabuhan diduga sangat menunjang pertumbuhan biota penempel pada kapal.

\subsection{Kelimpahan (N) Plankton}

Dalam penelitian jumlah plankton yang didapatkan di perairan Pelabuhan Benoa yaitu sebanyak 17 jenis. Kelimpahan plankton baik zooplankton maupun fitoplankton pada setiap stasiun berkisar 1.117.172 Individu/Liter- 1.626.163 Individu/Liter. Kelimpahan tertinggi terdapat pada stasiun 1 yaitu 1.626.163 Individu/Liter dan kelimpahan terendah terdapat pada stasiun 6 yaitu 1.117.172 Individu/Liter. Pengamatan pengukuran parameter fisika dan kimia yang dilakukan selama penelitian yaitu melihat kondisi perairan Pelabuhan Benoa terhadap kehidupan plankton.

Tingkat kesuburan perairan dapat ditentukan dengan karakteristik perairan salah satunya adalah kelimpahan fitoplankton (Madinawati, 2012). Berdasarkan hasil pengamatan yang dilakukan terhadap fitoplankton pada delapan stasiun di perairan Pelabuhan Benoa (Gambar 4), menunjukan besarnya jumlah spesies yang ditemukan pada tiap-tiap stasiun. Secara keseluruhan fitoplankton yang ditemukan yaitu pada kelas Bacillariophyceae dan kelas Dinophyceae. Ini sesuai pendapat yang dikemukakan oleh Widianingsih et al.,(2010) menyatakan bahwa diatom (Bacillarichyae) merupakan jenis dari golongan fitoplankton yang paling umum dijumpai dilaut. Diatome (Bacillariphyceae) dan Dinofagellata (Dinophyceae) merupakan jenis fitoplankton penting di laut untuk melihat kondisi pada suatu perairan.

Kelimpahan fitoplankton yang ditemukan selama penelitian berkisar antara 989.889- 622.222 Individu/Liter. Kelimpahan terendah ditemukan pada stasiun 4 yakni 622.222 Individu/Liter dan tertinggi pada stasiun 1 yakni 989.899 Individu/Liter. Widianingsih et al.,(2010) yang menyatakan bahwa kelimpahan fitoplankton > $12.500 \mathrm{sel} / 1$ termasuk kategori tinggi.

Tingginya kelimpahan fitoplankton pada stasiun 1 yang berada pada lokasi berlabuhnya kapal menyebabkan berbagai aktivitas meliputi pencucian kapal, pembuangan air blige kapal, limbah kemasan dan sisa perbekalan yang sudah tidak terpakai seperti sisa makanan yang berbahan organik maupun berupa sampah plastik dan baterai, serta dekat dengan kawasan mangrove, masuknya air dari sungai dan dekat dengan mangrove yang membawa zat-zat anorganik yang sangat dibutuhkan oleh fitoplankton. Keberadaan mangrove di sekitar muara sungai berpengaruh terhadap jumlah konsentrasi bahan organik dalam air yang dapat menyebabkan terjadinya unsurunsur hara di dalam air (Setiawan, 2013). Tingginya kelimpahan fitoplankton pada stasiun 7 yang berada pada lokasi berlabuhnya kapal perikanan yaitu memiliki aktivitas bongkar muat hasil tangkapan ikan, terdapat limbah alat tangkap (tali pancing, jaring,tali pelampung), air es yang digunakan sebagai pengawetan ikan, pencucian ikan dan limbah ikan itu yang menghasilakan limbah organik pada perairan Pelabuhan Benoa yang akan dimanfaatkan oleh fitoplankton sebagai sumber makanan. Tingginya kelimpahan fitoplankton pada stasiun 8 yang lokasinya terletak di mulut Teluk Benoa disebabkan oleh waktu pengambilan sampel yang dilakukan pada kondisi pasang menuju surut, sehingga ketika kondisi

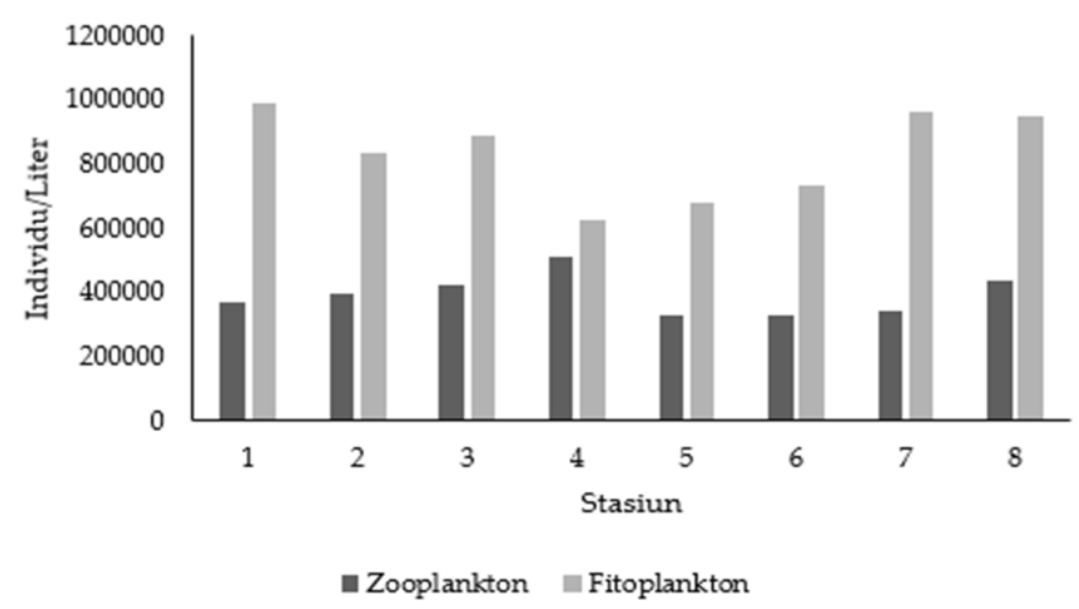

Gambar 4. Grafik Kelimpahan Plankton 
pasang beralih menuju kondisi surut volume air yang bergerak keluar dari teluk relatif tinggi, hal ini menyebabakan perpindahan fitoplankton yang terbawa oleh air tinggi, kondisi ini pula yang diduga menyebabkan jumlah fitoplankton hasil pengambilan sampel memiliki kelimpahan yang tinggi. Sementara stasiun 4 dan 5 yang terletak jauh dari daratan memiliki kelimpahan yang relatif rendah. Hal ini menjelaskan bahwa distribusi fitoplankton di perairan Pelabuhan Benoa tidak homogeny disebabkan oleh ketidakseragaman antara habitat yang satu dengan habitat lainnya, perbedaan habitat ini diantaranya dipengaruhi oleh arus, masukan air dari sungai, kedalaman perairan dan ketersediaan unsur hara. (Siburian et al.,2012) mengemukakan lingkungan pelabuhan merupakan subyek yang tidak dapat diprediksi kondisinya terkait dengan banyaknya parameter fisika kimia atau kontaminan yang masuk perairan. Pada kenyataannya hasil dari suatu kelompok tertentu dari dampak terhadap lingkungan perairan berhubungan dengan sirkulasi air, kualitas air, kualitas sedimen, dan kelimpahan biota.

Berdasarkan kelimpahan zooplankton masingmasing individu, selama pengamatan didapatkan dua jenis yang memiliki kelimpahan individu terbesar yaitu Palaemon sp, dan Carcinus sp. Keduanya berasal dari kelas Malacostraca. Palaemon sp. memiliki kelimpahan terbesar pada stasiun 1,2,3,5,6; sedangkan Carcinus sp. pada stasiun 4,7 dan 8. Hal tersebut mengindikasikan status kesuburan perairannya tergolong tinggi (Madinawati, 2012). Tingginya kelimpahan kedua jenis tersebut diduga karena kedua jenis tersebut memiliki daya adaptasi yang tinggi terhadap predasi dan perubahan parameter fisika kimia perairan (Gambar 2).

Kelimpahan total terbesar zooplankton terdapat pada stasiun 4 (dekat dengan perairan Tanjung Benoa dan perairan pulau serangan) yaitu sebesar 509.091 Individu/Liter dengan kelimpahan individu terbesar adalah Carcinus $s p$. sebesar 183.838 Individu/Liter. Tingginya kelimpahan total pada stasiun ini diduga karena parameter fisika kimia lingkungan seperti suhu, salinitas, kekeruhan, derajat keasaman, nitrat dan fosfat. Sedangkan kelimpahan terendah terdapat pada stasiun 5 dan 6 yaitu sebesar 325.253 Individu/Liter dengan kelimpahan individu terbesar dimiliki Palaemon sp. yaitu sebesar 169.697 Individu/Liter pada stasiun 5 dan 183.838
Individu/Liter pada stasiun 6 Menurut Faiqoh et al. (2015), bahwa ketika fitoplankton menurun, jumlah zooplankton akan menurun karena kekurangan makanan. Fitoplankton merupakan makanan zooplankton herbivor. Selain itu, kelimpahan zooplankton juga dipengaruhi oleh ikan-ikan pemakan zooplankton. Ketersediaan fitoplankton dan ikan pemakan zooplankton mempengaruhi populasi zooplankton. Nilai suhu disungai lebih rendah dibandingkan dengan dilaut juga mempengaruhi nilai kelimpahan zooplankton, dimana proses metabolisme dari zooplankton akan semakin cepat bila suhu bertambah besar sehingga nilai kelimpahan zooplankton di dekat sungai lebih kecil dibandingkan di laut.

\subsection{Struktur Komunitas}

3.3.1 Keanekaragaman $\left(\mathrm{H}^{\prime}\right)$, Keanekaragaman (E), dan Dominansi (D) Plankton

\section{a. Fitoplankton}

Hasil analisis struktur komunitas plankton di stasiun pengamatan (Tabel 3) mendapatkan hasil perhitungan Indeks Keanekaragaman $\left(\mathrm{H}^{\prime}\right)$ pada stasiun pengamatan mendapatkan indeks keanekaragaman yang berkisar antara 1.02-1.55. Indeks keanekaragaman terendah terdapat pada stasiun 6 yakni 1.02 dan yang tertinggi terdapat pada stasiun 1 yakni 1.55. Klasifikasi indeks Shannon-Wiener menunjukan bahwa relatif tidak terjadi perubahan dan secara umum termasuk dalam kisaran yang rendah yaitu $\mathrm{H}^{\prime}<2.3026$. Nilai kisaran indeks ini menjelaskan bahwa selama penelitian penyebaran jumlah individu tiap jenis rendah dengan keanekaragaman kecil serta kestabilan komunitas relatif rendah.

Tabel 3

Keanekaragaman $\left(\mathrm{H}^{\prime}\right)$, Keanekaragaman $(\mathrm{E})$, dan Dominansi (D) Fitoplankton

\begin{tabular}{cccc}
\hline Stasiun Keanekaragaman & Keseragaman & Dominansi \\
\hline 1 & 1.55 & 0.96 & 0.22 \\
2 & 1.10 & 0.92 & 0.33 \\
3 & 1.25 & 0.90 & 0.32 \\
4 & 1.25 & 0.78 & 0.34 \\
5 & 1.17 & 0.72 & 0.37 \\
6 & 1.14 & 0.71 & 0.41 \\
7 & 1.02 & 0.74 & 0.39 \\
8 & 1.07 & 0.96 & 0.35 \\
\hline
\end{tabular}




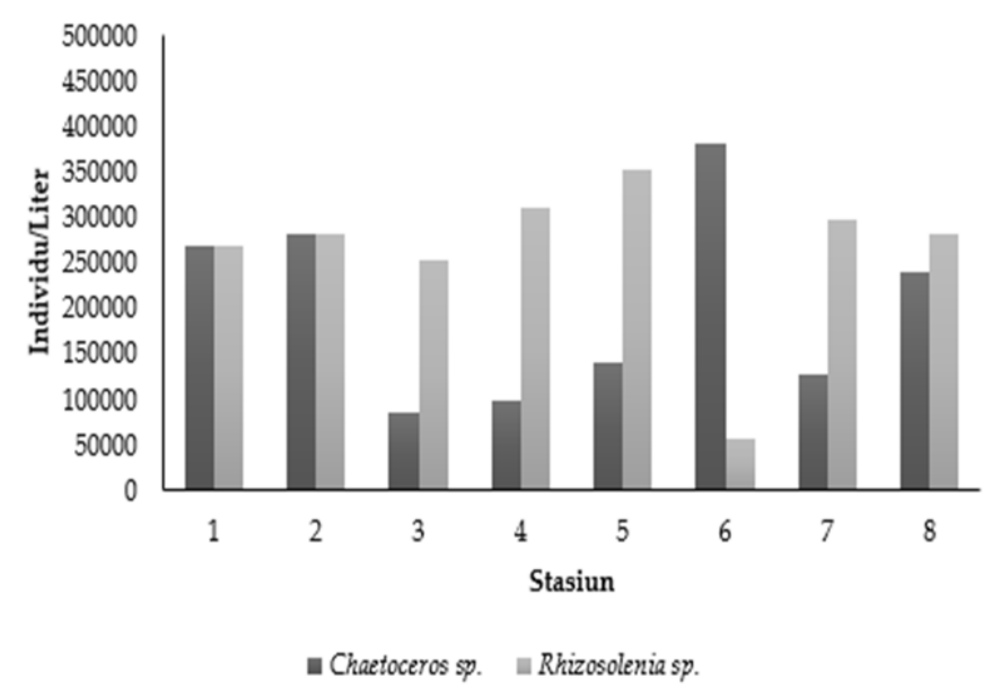

Gambar 5. Grafik Kelimpahan Plankton spesies $\alpha$ Mesosaprobik

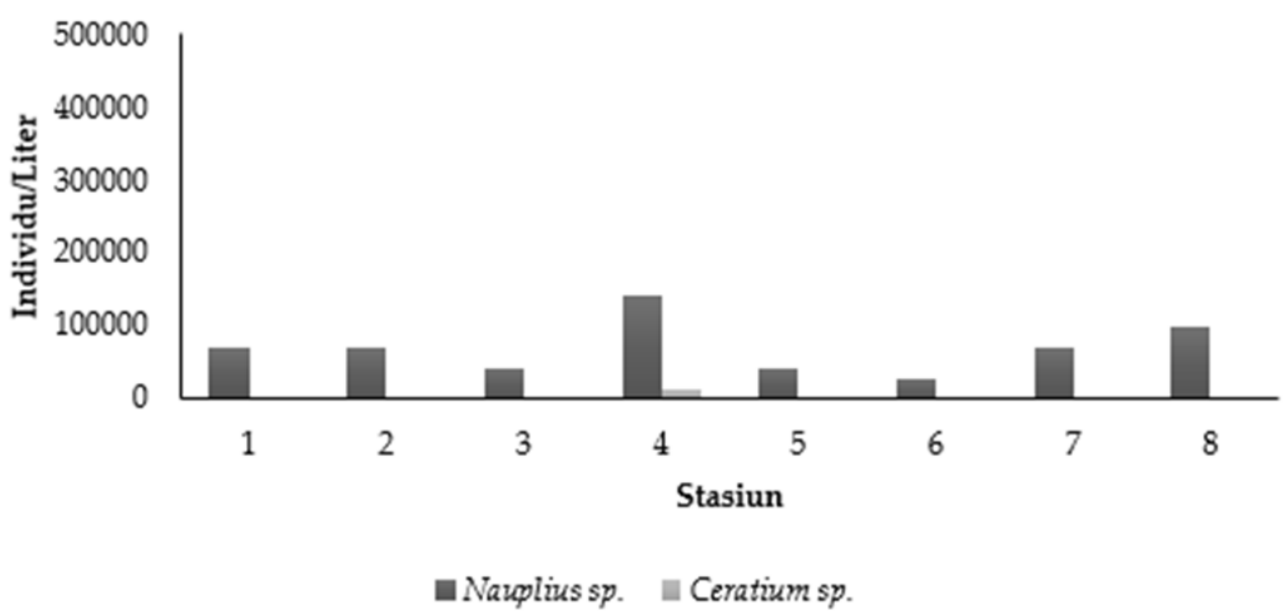

Gambar 6. Grafik Kelimpahan Plankton spesies $\beta$ Mesosaprobik

Nilai Indeks Keseragaman (E) menggambarkan seberapa besar kesamaan penyebaran jumlah individu tiap jenis. Indeks keseragaman memiliki hubungan terbalik dengan nilai indeks dominansi yaitu jika nilai indeks keseragaman tinggi maka indeks dominansi rendah begitu pula sebaliknya. Hasil pengamatan, nilai indeks keseragaman berkisar antara 0.71-0.96. Indeks keanekaragaman tertinggi ditemukan pada stasiun 1 yaitu 0.96 dan terendah terdapat pada stasiun 6 yaitu 0.71 . Secara umum Nilai E yang terhitung pada setiap waktu pengamatan berada pada kisaran diatas 0.5 hal ini menunjukan bahwa jumlah individu setiap jenis cenderung mendekati ketingkat yang seragam. Nilai E yang mendekati 1 menunjukan bahwa tingkat keseragaman pada suatu komunitas adalah semakin tinggi. Hal ini juga menerangkan bahwa jumlah individu setiap jenis pada suatu komunitas cenderung sama atau merata.
Hasil perhitungan Indeks Dominansi (C) pada setiap stasiun pengamatan didapatkan nilai yang relatif merata, yaitu berada pada kisaran 0.22-0.41. Indeks dominansi tertinggi terdapat pada stasiun 6 yaitu 0.41 dan terrendah terdapat pada stasiun 1 yaitu 0.22 atau kurang dari 0.5 yang tergolong relatif rendah, hal ini menunjukan bahwa tidak adanya dominansi suatu jenis fitoplankton pada suatu komunitas.

\section{b. Zooplankton}

Hasil analisis struktur komunitas zooplantkon di stasiun pengamatan (Tabel 4) mendapatkan indeks keanekargaman yang berkisar antara 1.06-1.58. Indeks keanekaragaman terendah terdapat pada stasiun 1 sebesar 1.06 dan tertinggi ditemukan pada stasiun 3 sebesar 1.58. Klasifikasi indeks 
Shannon-Wiener menunjukan bahwa kisaran nilai keanekaragaman pada seluruh stasiun pengamatan termasuk dalam kategori keanekaragaman rendah. Hal ini memberikan indikasi bahwa tekanan ekologi di lokasi penelitian cukup besar yang menyebabkan jumlah tiap jenis dan kestabilan komunitas rendah.

\section{Tabel 4}

Keanekaragaman $\left(\mathrm{H}^{\prime}\right)$, Keanekaragaman (E), dan Dominansi (D) Zooplankton

\begin{tabular}{cccc}
\hline Stasiun & Keanekaragaman & Keseragaman & Dominansi \\
\hline 1 & 1.06 & 0.73 & 0.43 \\
2 & 1.52 & 0.85 & 0.26 \\
3 & 1.58 & 0.88 & 0.24 \\
4 & 1.57 & 0.88 & 0.24 \\
5 & 1.43 & 0.8 & 0.32 \\
6 & 1.42 & 0.77 & 0.36 \\
7 & 1.38 & 0.86 & 0.29 \\
8 & 1.2 & 0.74 & 0.27 \\
\hline
\end{tabular}

Indeks keseragaman menggambarkan seberapa besar kesamaan penyebaran jumlah individu tiap jenis. Indeks keseragaman memiliki hubungan terbalik dengan nilai indeks dominansi yaitu jika nilai indeks keseragaman tinggi maka indeks dominansi rendah begitu pula sebaliknya. Hasil pengamatan, nilai indeks keseragaman berkisar antara 0.73-0.88. Indeks keseragaman tertinggi ditemukan pada stasiun 3 dan stasiun 4 yakni 0.88 sedangkan indeks keseragaman terendah terdapat pada stasiun 1 yakni 0.73 . Nilai indeks keseragaman ini tergolong dalam indeks keseragaman relatif tinggi yaitu (>0.5). Ini menyakan bahwa pada setiap komunitas zooplankton, memiliki perbandingan kelimpahan yang relative merata. Nilai indeks dominansi tertinggi terdapat pada stasiun 1 yakni 0.43 dan indeks dominansi terendah terdapat pada stasiun 3 dan stasiun 4 yakni 0.24. Keseragaman zooplankton yang tertinggi dengan dominansi yang relatif rendah ini berarti bahwa generagenera yang ditemukan pada masing-masing stasiun pengamatan memiliki komposisi yang seragam dan tidak terdapat salah satu genera yang mendominasi.

\subsection{Saprobik Indeks (SI) dan Tingkat Saptobik Indeks} (TSI)

Berdasarkan hasil identifikasi jenis dan kelimpahan plankton yang ditemukan di perairan Pelabuhan Benoa ditemukan 17 jenis plankton yang terdiri dari 2 jenis kelompok $\alpha$ Mesosaprobik (Gambar 5) memiliki rata-rata kelimpahan plankton berkisar 56.566-381.818 Individu/Liter dimana spesies Chaetoceros sp. yang memiliki kelimpahan tertinggi yaitu 381.818 Individu/Liter terdapat pada stasiun 6, 2 jenis kelompok $\beta$ Mesosaprobik (Gambar 6) memiliki rata-rata kelimpahan plankton berkisar 14.141-141.414 Individu/Liter dimana spesies Nauplius $s p$. memiliki kelimpahan tertinggi yaitu 141.414 Individu/Liter terdapat pada stasiun 4, 1 jenis kelompok Oligosaprobik (Gambar 7) memiliki rata-rata kelimpahan plankton berkisar 155.556523.232 Individu/Liter dimana spesies Skeletonema sp. memiliki kelimpahan tertinggi yaitu 523.232 Individu/Liter terdapat pada stasiun 7 dan 12 jenis kelompok Non Saprobik (Gambar 8) memiliki ratarata kelimpahan plankton berkisar 14.141-353.535

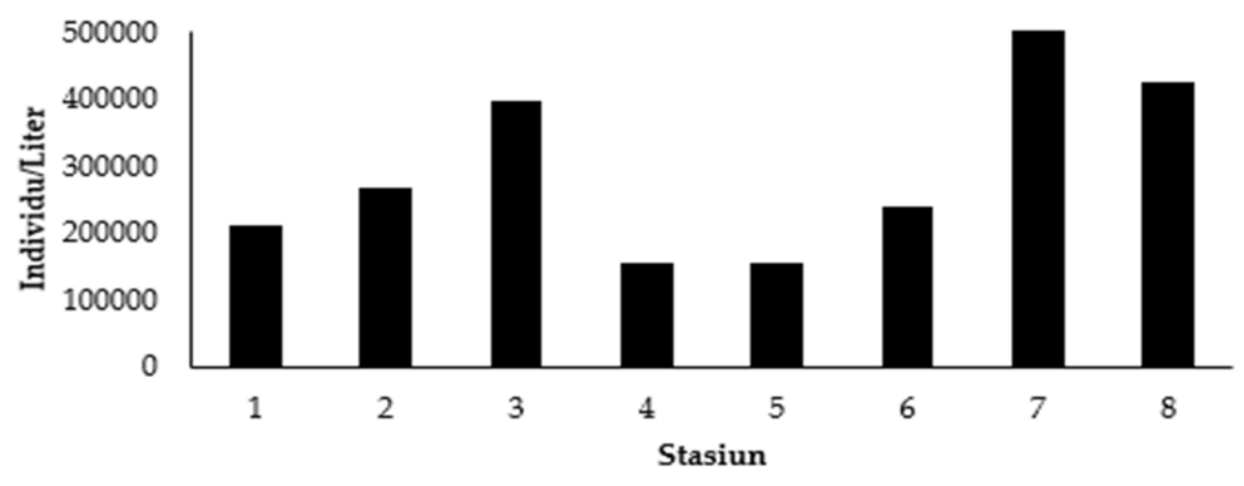

- Skeletonena sp.

Gambar 7. Grafik Kelimpahan Plankton spesies Oligosaprobik 


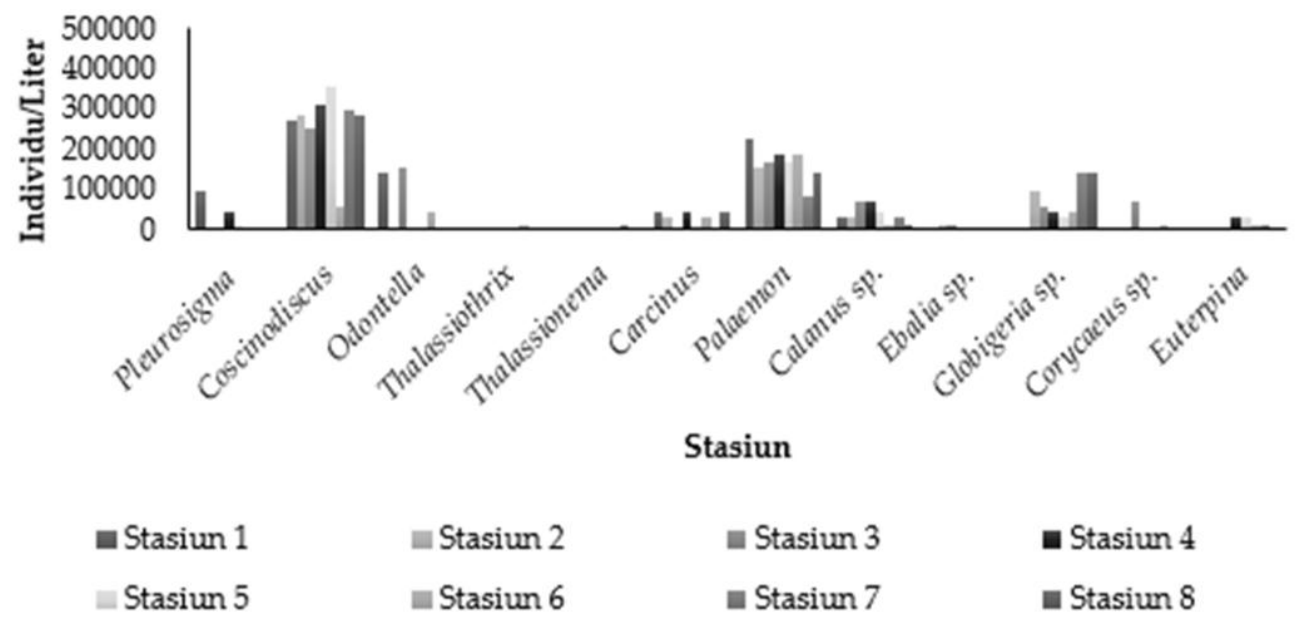

Gambar 8. Grafik Kelimpahan Plankton Non saprobik

Individu/Liter dimana spesies Coscinodiscus sp. memiliki kelimpahan tertinggi yaitu 353.535 Individu/Liter terdapat pada stasiun 5.

Dilihat pada kelimpahan plankton non saprobik pada spesies Coscinodiscus sp. dari 8 stasiun pengamatan menunjukan bahwa kelimpahan plankton tertinggi di perairan Pelabuhan Benoa berkisar antara 56.566-353.535 Individu/Liter. Tingginya kelimpahan pada spesies ini di duga kondisi lingkungan tempat penelitian yang berada di dalam teluk, sehingga hanya ada satu kelas yang mendominasi jenis di perairan Pelabuhan Benoa.

Berdasarkan perhitungan SI terlihat bahwa nilai SI plankton berkisar antara 1.0-1.6. Berdasarkan kriteria tingkat pencemaran perairan menunjukan bahwa perairan Pelabuhan Benoa berada dalam kondisi tercemar ringan sampai dengan tercemar sangat ringan. Berdasarkan perhitungan TSI terlihat bahwa nilai TSI plankton berkisar antara 1.76-1.96. (Tabel 5).

Pada stasiun 1,2,6 dan 8 diperoleh SI yang sama yaitu 1.6, dan nilai TSI yang hampir sama yaitu sebesar 1.92-1.96. Pada stasiun 3,4,5, dan 7 nilai SI mempunyai nilai yang hampir sama yaitu 1.0-1.5 dan nilai TSI yaitu berkisar antara 1.76-1.89. Ini menyatakan bahwa kriteria tingkat pencemaran di perairan Pelabuhan Benoa berada dalam kondisi tercemar ringan sampai dengan tercemar sangat ringan atau belum tercemar. (Utomo et al., 2013) mengemukakan tingkat saprobik di suatu perairan yang menunjukkan tingkat pencemaran ringan disebabkan oleh bahan pencemar anorganik.
Dilihat dari hasil penelitian indeks keanekargaman plankton di perairan Pelabuhan Benoa berkisar 2.26-2.83.

Secara keseluruhan berdasarkan nilai SI dan TSI perairan Pelabuhan Benoa masih dalam tingkat kategori pencemaran ringan sampai belum tercemar. Hal tersebut perlu diperkuat dengan keadaan faktor lingkungan di perairan Pelabuhan Benoa. Seperti pada stasiun 3 dan stasiun 7 memiliki nilai SI lebih kecil dari stasiun yang lainnya dikarenakan dekat dengan mangrove, aliran sungai dan daratan. Menurut, AS Awaludin et al., (2015) yang menyatakan bahwa kondisi perairan yang mengalami pencemaran ringan biasanya dijumpai adanya bahan pencemar berupa organik.

Tabel 5

Hasil Saprobik Indeks dan Tingkat Saprobik Indeks

\begin{tabular}{|c|c|c|c|c|}
\hline Stasiun & SI & Kelompok & TSI & Kelompok \\
\hline 1 & 1.6 & $\begin{array}{l}\beta \text {-meso/oligo } \\
\text { saprobik }\end{array}$ & 1.92 & Oligosaprobik \\
\hline 2 & 1.6 & $\begin{array}{l}\beta \text {-meso/oligo } \\
\text { saprobik }\end{array}$ & 1.96 & Oligosaprobik \\
\hline 3 & 1.0 & $\begin{array}{l}\beta \text {-meso/oligo } \\
\text { saprobik }\end{array}$ & 1.93 & Oligosaprobik \\
\hline 4 & 1.4 & $\begin{array}{l}\beta \text {-meso/oligo } \\
\text { saprobik }\end{array}$ & 1.76 & Oligosaprobik \\
\hline 5 & 1.5 & $\begin{array}{l}\beta \text {-meso/oligo } \\
\text { saprobik }\end{array}$ & 1.77 & Oligosaprobik \\
\hline 6 & 1.6 & $\begin{array}{l}\beta \text {-meso/oligo } \\
\text { saprobik }\end{array}$ & 1.83 & Oligosaprobik \\
\hline 7 & 1.0 & $\begin{array}{l}\beta \text {-meso/oligo } \\
\text { saprobik }\end{array}$ & 1.89 & Oligosaprobik \\
\hline 8 & 1.6 & $\begin{array}{l}\beta \text {-meso/oligo } \\
\text { saprobik }\end{array}$ & 1.95 & Oligosaprobik \\
\hline
\end{tabular}




\section{Simpulan}

Dari hasil penelitian yang dilakukan dapat diambil kesimpulan telah ditemukan 17 genera plankton yang ditemukan dilokasi penelitian yaitu dari kelas Bacillariophyceae, Dinophyceae pada fitoplankton dan kelas Magnoliopsida, Malacostraca, Maxillopoda, Globothalamea dan Hexanauplia. Kelimpahan total plankton berkisar 1.117.172 Individu/Liter $\quad 1.626 .163 \quad$ Individu/Liter. Berdasarkan indeks keanekaragaman pada zooplankton berkisar antara 1.06-1.58 dan fitoplankton 1.02-155, ini menunjukkan bahwa nilai keanekaragaman pada seluruh stasiun pengamatan termasuk dalam kategori keanekaragaman rendah, nilai indeks keseragaman zooplankton berkisar 0.73-0.88 dan fitoplankton berkisar 0.71-0.96 ini menunjukkan bahwa indeks keseragaman relatif tinggi, dan nilai dominansi zooplankton berkisar 0.24-0.43 dan fitoplankton berkisar 0.22-0.41 ini menunjukan bahwa dominansi yang relatif rendah.

Nilai SI berkisar antara 1.0-1.6 dan TSI berkisar antara 1.76-1.96, ini menunjukan bahwa perairan Pelabuhan Benoa dikategorikan perairan dalam kondisi tercemar ringan sampai belum tercemar.

\section{Ucapan terimakasih}

Penulis mengucapkan terimakasih kepada penyelenggara pendidikan program Bidikmisi yang sudah memberikan bantuan biaya hidup dan bantuan penyelenggara pendidikan, Laboratorium GIS yang sudah memberikan dan menyediakan fasilitas dalam proses menyelesaikan jurnal skripsi saya.

\section{Daftar Pustaka}

Amengual-Morro, C., Niell, G. M., \& Martínez-Taberner, A. (2012). Phytoplankton as bioindicator for waste stabilization ponds. Journal of Environmental Management, 95, S71-S76.

Awaludin, Z., Safuan, M., Okajima, T., \& Ohsaka, T. (2015). Investigating the physical and electrochemical effects of cathodic polarization treatment on $\mathrm{TaO}$ x. Journal of Materials Chemistry A, 3(32), 16791-16800.

Anggraini, A., Sudarsono, S., \& Sukiya, S. (2016). Kelimpahan dan Tingkat Kesuburan Plankton di Perairan Sungai Bedog . Jurnal Biologi-S1, 5(6), 1-9.

Boesono, H. (2008). Pengaruh lama perendaman terhadap organisme penempel dan modulus elastisitas pada kayu. Jurnal Ilmu Kelautan, 13(3), 177180.
Damaianto, B. B., \& Masduqi, A. A. (2014). Indeks Pencemaran Air Laut Pantai Utara Kabupaten Tuban dengan Parameter Logam. Jurnal Teknik ITS, 3(1), 1-4.

Faiqoh, E., Ayu, I. P., Subhan, B., Syamsuni, Y. F., Anggoro, A. W., \& Sembiring, A. (2015). Variasi Geografik Kelimpahan Zooplankton di Perairan Terganggu, Kepulauan Seribu, Indonesia. Journal of Marine and Aquatic Sciences, 1(1), 19-22.

Gharib, S. M., El-Sherif, Z. M., Abdel-Halim, A. M., \& Radwan, A. A. (2011). Phytoplankton and environmental variables as a water quality indicator for the beaches at Matrouh, south-eastern Mediterranean Sea, Egypt: an assessment. Oceanologia, 53(3), 819-836.

Hariyati, L., Syah, A. F., \& Triajie, H. (2010). Studi Komunitas Fitoplankton di Pesisir Kenjeran Surabaya Sebagai Bioindikator Kualitas Perairan. Jurnal Kelautan: Indonesian Journal of Marine Science and Technology, 3(2), 117-131.

Junqueira, M. V., Friedrich, G., \& De Araujo, P. R. P. (2010). A saprobic index for biological assessment of river water quality in Brazil (Minas Gerais and Rio de Janeiro states). Environmental monitoring and assessment, 163(1-4), 545-554.

Madinawati, M. (2012). Kelimpahan dan Keanekaragaman Plankton di Perairan Laguna Desa Tolongano Kecamatan Banawa Selatan. Jurnal Media Litbang Sulteng , 3(2), 119-123.

Makmur, M., Kusnoputranto, H., Moersidik, S. S., \& Wisnubroto, D. S. (2013). Pengaruh limbah organik dan rasio $\mathrm{n} / \mathrm{p}$ terhadap kelimpahan fitoplankton di kawasan budidaya kerang hijau Cilincing. Jurnal Teknologi Pengelolaan Limbah, 15(2),52-53.

Nastiti, A. S., Putri, M. R. A., \& Hartati, S. T. (2016). Hubungan Antara Kelimpahan Meroplankton Dengan KualitaS Perairan Di Teluk Jakarta. Jurnal Bawal Widya Riset Periakanan Tangkap, 8(2),91-100.

Nontji, A. (2008). Plankton laut. Jakarta, Indonesia: LIPI Press.

Ramadhan, F., Rijaluddin, A.F.,\& Mardiyansyah (2016). Studi Indeks Saprobik dan Komposisi Fitoplankton pada Musim Hujan di Situ Gunung, Sukabumi, Jawa Barat. Jurnal Biologi, 9(2), 95-102.

Rahayu, S.,Setyawati, T.R., Turnip. M.(2013). Struktur Komunitas Zooplankton di Muara Sungai Mempawah Kabupaten Pontianak Berdasarkan Pasang Surut Air Laut. Al-Kauniyah: Jurnal Biologi, 9(2), 95-102.

Sahara, E., Widihati, I. A. G., \& Putra, I. G. D. 2015. Fraksinasi dan Biovailabilitas Logam Berat Fe dan Mn Pada Sedimen di Pelabuhan Benoa. Jurnal Kimia, 9(1), 124-131.

Sarinda, F., \& Dewiyanti, I. (2013). Keragaman fitoplankton di perairan estuaria Kuala Gigieng Kabupaten Aceh Besar, Provinsi Aceh. Depik Jurnal Ilmu-Ilmu Perairan, Pesisir dan Perikanan, 2(1), 20-25. 
Setiawan, H. (2013). Status ekologi hutan mangrove pada berbagai tingkat ketebalan. Jurnal Penelitian Kehutanan Wallacea, 2(2), 104-120.

Siburian, R., Simatupang, L., \& Bukit, M. (2017). Analisis Kualitas Perairan Laut Terhadap Aktivitas Di Lingkungan Pelabuhan Waingapu-Alor Sumba Timur. Jurnal Pengabdian Kepada Masyarakat, 23(1), 225-232.

Suryanti, S. (2008). Kajian Tingkat Saprobitas di Muara Sungai Morodemak Pada Saat Pasang dan Surut. Jurnal Saintek Perikanan, 4(1), 76-83.
Thoha H, Rachman A. (2013). Kelimpahan dan distribusi spasial komunitas plankton di perairan kepulauan banggai. Jurnal Ilmu dan Teknologi Kelautan Tropis. 5(1), 145-161.

Utomo, Y., Priyono,B., Ngabekti,S. (2013). Saprobitas Perairan Sungai Juwana Berdasarkan Bioindikator Plankton. Journal Life Sci Unes, 2(1), 2-8.

Widianingsih, W., Hartati, R., Djamali, A., \& Sugestiningsih, S. (2010). Kelimpahan dan Sebaran Horizontal Fitoplankton di Perairan Pantai Timur Pulau Belitung. Journal of Marine Sciences, 12(1), 6-11.

(C) 2017 by the authors; licensee Udayana University, Indonesia. This article is an open access article distributed under the terms and conditions of the Creative Commons Attribution license (http://creativecommons.org/licenses/by/3.0/). 